\title{
The Role Social Media in Forming Religious Identity of Veiled Female Students in Higher Education (Study on Veiled Students Phenomena at College in Gorontalo)
}

\author{
A Zaenuri ${ }^{1}$, Lahaji $^{2}$, H Yusuf $^{3}$ \\ Faculty of Tarbiyah and TeachingSciences, IAIN Sultan Amai, Gorontalo ${ }^{1,3}$ \\ Faculty of Islamic Law, IAIN Sultan Amai, Gorontalo ${ }^{2}$

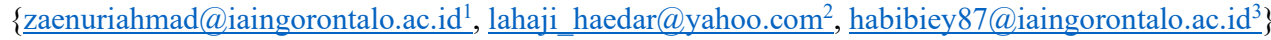

\begin{abstract}
Since the last five years, the growth of veiled students in higher education in Gorontalo has experienced a significant increase. Data from the research conducted by Gorontalo Muhammadiyah University on the growth of veiled students on the Islamic campus show an increase every year. In 2014 the number of female students worn Burqa was as much as 5\% of the total students than in 2015 increased to $15 \%$ and in 2016 to 2017 the number of them reached close to $30-40 \%$. This study investigates the role of social media informing the religious identity of the veiled female students in higher education in Gorontalo. By using a survey approach, this study is expected to find answers to the extent to which social media can form one's religious identity. The theory used in this study is self constructs identity by Erickson. The results of the study show that social media has a role in forming the religious identity of veiled students in relation to following the edicts of scholars and admired figures.
\end{abstract}

Keywords: Social Media, Religious Identity, Burqa

\section{Introduction}

Starting from the last five years, the religious motivation of students in Gorontalo indicated a significant increase [1]. The increase was seen with the increasing number of religious studies with the theme of "Hijrah" and other religious "obedience" symbols such as the emergence of the Hijabers-student community with a hijab model that almost covers the whole body - a community of Muslim youth who wear trousers that are not enough to the ankles or commonly called "cingkrang" pants and the increasing number of veil users (Burqa) on college environment.

Especially for the veil phenomenon, the phenomenon becomes a problem caused by two things that seem to face each other. On the one hand, wearing the veil is the freedom of expression of someone to get the dressing, on the other hand, the veil may restrict the space for student social interaction to other students or even to the lecturer. To date, there are no strict rules in the form of legal-formal issued by the college in Gorontalo in dealing with this phenomenon.

The growth of veil users in college has experienced a significant increase. This can be seen in the following table data; 
Table 1. The growth of veil users on collage in Gorontalo

\begin{tabular}{|c|c|c|c|c|c|}
\hline & & Frequency & Percent & $\begin{array}{l}\text { Valid } \\
\text { Percent }\end{array}$ & $\begin{array}{l}\text { Cumulative } \\
\text { Percent }\end{array}$ \\
\hline \multirow[t]{5}{*}{ Valid } & 2016 & 3 & 9,4 & 10,3 & 10,3 \\
\hline & 2017 & 3 & 9,4 & 10,3 & 20,7 \\
\hline & 2018 & 16 & 50,0 & 55,2 & 75,9 \\
\hline & 2019 & 7 & 21,9 & 24,1 & 100,0 \\
\hline & Total & 29 & 90,6 & 100,0 & \\
\hline Missing & System & 3 & 9,4 & & \\
\hline Total & & 32 & 100,0 & & \\
\hline
\end{tabular}

The data above show that $10.3 \%$ of students who wear the veil are students in the class of 2016. The same number also occurs in the class of 2017 students. The greatest number is in the class of 2018 students, which is as much as $50 \%$ and the latest generation or class of 2019 less than the previous year which is as much as $24 \%$.

The question then is, why did the number of veiled students decrease in 2019? This decrease was because forming religious identity began to be formed. Many new students started wearing the veil (burqa). This data is reinforced by the data submitted with the question, since when did students in Gorontalo use the veil (burqa)? Most answered in their first year or early years in college. Thus, the college has an important role in shaping the religious identity of veiled students.

The next problem is what factors contribute to forming the identity of the personality? This question was answered with the initial hypothesis that 4 out of 32 veiled students wore the veil because they had followed studies by several religious teachers through social media. Such conditions on one hand can be justified, but social media does not have the verification of the truth of the teachings delivered. Understanding Islamic law through social media is simplified and takes the easiest and most interesting discussion so it increases the number of followers, likes, and subscribers.

Through this research, the writer tries to explore further the role of social media informing the religious identity of veiled (burqa) students in Gorontalo.

\section{Method}

This research is field research using a survey approach. Survey research was chosen because the subject, object, and nature of the study were approached with statistical procedures. The data source in this study is the number of respondents determined according to the stratified random sampling method. In this study, researchers act as the main instrument.

The location of this study took three famous collages in Gorontalo. Those are Gorontalo State University, Gorontalo Muhammadiyah University, and IAIN Sultan Amai Gorontalo. Analysis of the data in this study uses qualitative-descriptive analysis. This is done in order to reveal the meaning behind the numbers presented.

\section{Result and Discussion}

\section{Grand Theories of Social Media and Religious Creation}


Erickson defines self-identity as a self-portrait composed of various types of identity. These identities such as career identity, political identity, religious identity, relationship identity with others, intellectual identity, sexual identity, ethnic identity, desire identity, personality identity, and physical identity [2], [3]. If it is related to religious identity then the identity in question is a portrait or feature of religious attitudes attached to someone who distinguishes it from the others.

As the inventor of the theory of self-identity formation, Erickson suggests several things that can affect the formation of identity in a person including:

a. Social environment, where a person grows and develops like family, neighbors and peer groups.

b. Reference group is a group formed in someone such as a religious group or a group that has the same interests where through these groups adolescents can obtain values and roles that can be a reference for themselves.

c. Idol figure, that is someone who is very meaningful like a friend, teacher, brother, or someone they admire [2][3].

These three things play an important role in shaping a person's personality or religious identity. How is the social environment and what groups, both religion, and society, as well as their idol figures who will later form one's identity, will be formed?

In its relationship with social media, it places the role of social media on the extent to which the media shapes one's religious identity through the factors of identity formation as mentioned above. Because it is believed, social media has sufficient social power in influencing individual opinions on issues that develop in society. Supporting or mass movement can be formed because the power of online media is caused by what is in social media. This proof in shaping public or community opinions, attitudes, and behavior (Riswandari, 2017).

As social media sites began to emerge, broadly social media can be regarded as an online medium. Users of this media through internet-based applications can share, participate, and create content in the form of blogs, wikis, forums, social networks, and virtual world spaces that are supported by increasingly sophisticated multimedia technology. The Internet, social media and multimedia technology are inseparable. Currently, the most popular and growing social media are social networks, YouTube, Instagram, Twitter, Facebook.

According to Eisenberg (Pakuningjati, 2015: 6) concludes social media in a more effective and easily understood definition as an online platform for interacting, collaborating and creating or sharing various kinds of digital content. Social media is used to interact with users to make it easier to get information quickly and completely. In its development, social media appears as a new medium that is much loved, so it becomes a means needed by many people and not a stranger in society.

\section{The Role of Social Media in Creating Student Religious Identity}

Erickson stated that religious identity can be formed through a social environment that includes family, neighbors, and peers. In relation to social media, peers can be groups of friends in a virtual network. Based on the results obtained data that $53.1 \%$ of veiled students in Gorontalo are active Facebook users. $71.9 \%$ are YouTube viewers of Scholars studies every day on social media. Thus, this social environment also plays a role in shaping the religious identity of veiled students. 


\section{Friends on Social Media}

The development of social media currently provides a place for users to interact more widely without being obstructed by distance and time to anyone. Communication on social media forms an interaction between individuals and their social environment through cyberspace. This interaction will then encourage someone to construct their identity online. As research cited by Rulli Nasrullah (2012: 113), the 2008 Graham Nichols Dixon Thesis entitled Instant Validation: Testing Identity on Facebook. The results showed that the existence of cyberspace and the emergence of social media such as Facebook has taken a new direction on how a person or group of people construct their identity online.

Friendship on social media in creating the religious identity of veiled students plays an influential role in confirming the decision to wear the veil. Based on the results of descriptive statistical analysis, it is obtained that $9.4 \%$ of students have friendships in social media with religious teachers who advocate using veils. $25 \%$ of them are followers, $6.3 \%$ like to share content about the veil and $3.1 \%$ subscribe to the content.

Tabel 2. Friendship on Social Media

\begin{tabular}{|c|c|c|c|c|c|}
\hline & & Frequency & Percent & $\begin{array}{l}\text { Valid } \\
\text { Percent }\end{array}$ & $\begin{array}{l}\text { Cumulative } \\
\text { Percent }\end{array}$ \\
\hline \multirow[t]{6}{*}{ Valid } & Be Friends & 3 & 9,4 & 10,0 & 10,0 \\
\hline & Followers & 8 & 25,0 & 26,7 & 36,7 \\
\hline & $\begin{array}{ll}\begin{array}{l}\text { Share the } \\
\text { content }\end{array} & \\
\end{array}$ & 2 & 6,3 & 6,7 & 43,3 \\
\hline & Subscriber & 1 & 3,1 & 3,3 & 46,7 \\
\hline & None & 16 & 50,0 & 53,3 & 100,0 \\
\hline & Total & 30 & 93,8 & 100,0 & \\
\hline Missing & System & 2 & 6,3 & & \\
\hline Total & & 32 & 100,0 & & \\
\hline
\end{tabular}

The position of a friend as a preference to use can be said to be quite large. If added up the position reaches approximately 50\%. Through friendship, the veiled students communicate online and continue in offline meetings, form groups and establish meetings (khalaqah), and even form their own organizations in religious studies. This is similar to what was revealed by Yusran, a student of the Faculty of Tarbiyah and Teacher Training who wore a veil.

"I wore the veil when I first joined the campus. I interacted with religious study groups on campus. At first, it was a bit embarrassed when I first put on the veil. But after a long time and many who wear the veil, I feel comfortable wearing it."

The results of the interview above strengthen the conclusion that the social environment in the form of friends also helps create the identity of the veiled student personality.

\section{Reference Groups}


Erickson states a reference group is a group formed in someone who has the same interests. As for what is included in the group here is the religious group. The group can be "khalaqa", or other religious organizations.

Veiled (burqa) students spread across several campuses in Gorontalo many of them are followers of Islamic organizations. There is hardly an Islamic organization whose members are not veiled. Even to the Nahdlatul Ulama organization, which explicitly rejects the use of veils (burqa) throughout Indonesia. Such conditions indicate that the position of students in an Islamic organization can still be influenced by other factors that cause a person to wear a veil.

Data from the results of descriptive analysis showed that $9.4 \%$ of veiled students on several campuses in Gorontalo were followers of the Nahdlatul Ulama religious organization. $18.8 \%$ are followers of the Wahdah Islamiyyah organization. 9.4\% followers of the Salafi sect and $28.1 \%$ are Jamaah Tabligh. $12.5 \%$ of followers of religious organizations other than the above organizations and $21.9 \%$ did not answer

Tabel 3. Religious Organization of Veiled (Burga) Students in Gorontalo

\begin{tabular}{llllll}
\hline \multirow{7}{*}{ Valid } & & Frequency & Percent & $\begin{array}{l}\text { Valid } \\
\text { Percent }\end{array}$ & $\begin{array}{l}\text { Cumulative } \\
\text { Percent }\end{array}$ \\
\cline { 2 - 6 } & NU & 3 & 9,4 & 12,0 & 12,0 \\
\cline { 2 - 6 } & Wahdah & 6 & 18,8 & 24,0 & 36,0 \\
\cline { 2 - 6 } & Salafi & 3 & 9,4 & 12,0 & 48,0 \\
\cline { 2 - 6 } & Jamaah Tabligh & 9 & 28,1 & 36,0 & 84,0 \\
\cline { 2 - 6 } & Others & 4 & 12,5 & 16,0 & 100,0 \\
\cline { 2 - 6 } & Total & 25 & 78,1 & 100,0 & \\
\hline Missing & System & 7 & 21,9 & & \\
\hline Total & & 32 & 100,0 & & \\
\hline
\end{tabular}

Specifically, for religious organizations such as Wahdah Islamiyyah, Salafi and Jamaah Tabligh are groups that explicitly order their followers to wear the veil, it is likely that followers will obey the advice of the clerics of the organization. This view is in line with the opinion of Muhammad Nasiruddin Al-Ban, a well-known cleric in Saudi Arabia and several other scholars who argued that the face is not part of the obligatory covering, but because of the rampant immorality, he advocated using it [5]. Bani gives the criteria for a good Muslim veil or covering: 1) Hijab must cover the whole body, 2) Should not invite lust, 3) Hijab is a thick and not transparent clothing, 4) Hijab is a loose or not tight clothing, 5) Clothing does not resemble men, 6) Clothing does not resemble unbelievers, 6) Clothing may not reflect the luxury of the world.

Besides expressly ordering the wearing of the veil in any religious material presented, the three groups of religious organizations above are considered quite successful in ordering their followers to wear the veil. This is because of the support of the wing organizations which are held every week in the form of the khalaqah usrah. The Wahdah Islamiyyah religious organization, for example, has a special women's organization comprising veiled women. Likewise, with the women's organization, Jamaah Tabligh called Masturah and also not much different from the Salafi group and it turns out that many veiled students on campus are adherents and followers of the organization.

The offline meeting (khalaqah) group is growing because it is supported by the ease of information through WhatsApp, Facebook and Twitter groups, which then affects students in wearing the veil. 
Fig 1. Social Media Network about Veils (Burqa)

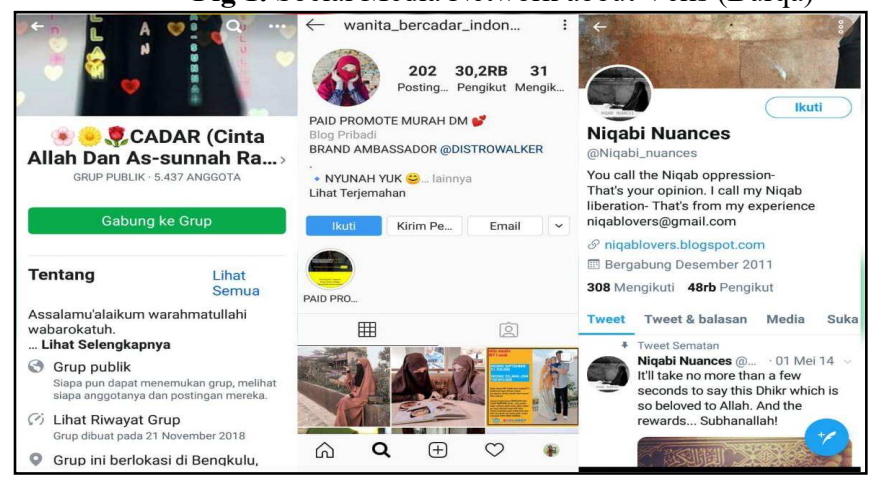

The opposite condition is in the Nahdlatul Ulama religious organization. The main figures in the organization strongly reject the veil in Indonesia, but some students veiled admit they are part of the organization. Several factors can cause this, one of which is the internal influence of the organization which is not stronger in influencing individual students due to students being part of the organization because of heredity and not understanding.

\section{Idol figures}

Besides religious organizations, admiration for Religious Figures also contributes to shaping student religious identity. Through social media, religious organizations, khalaqah and other similar activities, students study Islam and admire the scholars who conveyed the importance of veiling.

Scholars admired by veiled students in Gorontalo are scholars whose a view that the veil is compulsory. They are like Ustadz Khalid Basalamah or at least show that wearing a veil is far better than wearing a hijab in general. While the opposite cleric, or cleric who believes that the veil is permissible or even an Islamic tradition that is recognized by Islam such as Idrus Ramli, is not known by students.

As for the data about the awe of the veiled students at the scholars, they obeyed as follows:

Tabel 4. Social Media Scholars Admired

\begin{tabular}{llllll}
\hline \multirow{2}{*}{ Valid } & & Frequency & Percent & $\begin{array}{l}\text { Valid } \\
\text { Percent }\end{array}$ & $\begin{array}{l}\text { Cumulative } \\
\text { Percent }\end{array}$ \\
\cline { 2 - 6 } & Abdul Shamad & 11 & 34,4 & 35,5 & 35,5 \\
\cline { 2 - 6 } & Adi Hidayat & 8 & 25,0 & 25,8 & 61,3 \\
\cline { 2 - 6 } & Khalid Basalamah & 6 & 18,8 & 19,4 & 80,6 \\
\cline { 2 - 6 } & Firanda Andirja & 4 & 12,5 & 12,9 & 93,5 \\
\cline { 2 - 6 } & Syafiq Reza Basalamah & 2 & 6,3 & 6,5 & 100,0 \\
\cline { 2 - 6 } & Total & 31 & 96,9 & 100,0 & \\
\hline Missing & System & 1 & 3,1 & & \\
\hline Total & & 32 & 100,0 & & \\
\hline
\end{tabular}

Based on the above table, it is known that Abdul Shamad is the most prominent religious figure in his lecture by students who wear veils in Gorontalo. These data support the conclusion that both the social environment of peers and role models influence in creating the 
identity of the veiled student personality. This is indicated by many religious lecture content, which states that using the veil is far better than the use of the veil in general.

Thus it was concluded that, from the three factors that formed personality identities as mentioned by Erickson, the social environment, reference groups, and idol figures, each helped create the religious identity of veiled students in Gorontalo.

\section{Conclusion}

Based on the discussion above, it can be concluded thatSocial media has an important role in creating the religious identity of veiled students in several ways. First, creating a virtual network of friends that is followed up on offline weekly meetings and religious studies in the Khalaqah group. Second, improve online communication in sharing information about religious studies and inter-group meetings. Third, bring up public figures who can be role models to be admired, especially scholars whom they recognize from social media.

Other external factors that also create the identity of veiled student personalities include, the social environment in the form of peers and close friends in the Khalaqah, religious organizations that are followed as well as social media scholars who are admired and obeyed.

\section{References}

[1] P. BPS, "Gorontalo is one of the 34 provinces in Indonesia which has a large Muslim population. The number reached $96.87 \%$ of the total population.If sorted nationally, Gorontalo is the region with the third largest Muslim population after the Special Region of Nang," in Comparation withdata BPS-Statistics Of Sumatera Barat Provice, Sumatra Barat: Graphic Dwipa, 2018, p. 298.

[2] E. H. Erikson, Identitas dan Siklus Hidup Manusia. Jakarta: Gramedia, 1989.

[3] U. Hasanah, "Pembentukan Identitas Diri Dan Gambaran Diri Pada Remaja Putri Bertato Di Samarinda," vol. 1, no. 2, pp. 177-86, 2013.

[4] N. Riswandari, "Dominasi Media Sosial dalam Arus Informasi; Kajian Terhadap Aksi Bela Islam," vol. 4, no. 1, pp. 26-33, 2017.

[5] H. Rahman, "Cadar Perspektif Mufassir: Interpretasi Mufasir Salaf Hingga Mutaakhirin Terhadap Ayat 59 Surah al-Ahzab," Diya Al Afkar, vol. 5, no. 1, 2017. 